(2020), 3 (1): 14-18

\title{
USING GROUP WORK STRATEGY TO IMPROVE STUDENTS’ READING COMPREHENSION SKILL
}

\author{
Adib Ahmada \\ Institut Agama Islam Darussalam Banyuwangi \\ adibahmada@iaida.ac.id
}

\begin{abstract}
The reading comprehension skill of the First Semester class of English Education Department of Islamic Institute of Darussalam Blokagung Banyuwangi in Academic Year 2018/2019 was low. It could be seen based on the result of preliminary study that was conducted by the researcher. Therefore, the researcher tried to use group work strategy to solve the problems. Since the study aimed to improve the students' reading comprehension skill, the researcher used a Classroom Action Research as a research design. This research was conducted at the First Semester class of English Education Department of Islamic Institute of Darussalam Blokagung Banyuwangi that consists of 25 students. To measure their improvement in reading comprehension, the lecturer had determined the criteria of success. It was if the students reached the score above 70 . The researcher found that group work strategy could improve students' reading skill. The students reading skill increased from $24 \%, 64 \%$, to $92 \%$ (preliminary study, the first cycle and the second cycle).
\end{abstract}

Keywords: group work, reading comprehension skill

CPendidikan Bahasa Inggris FPISH IKIP BU Malang

\section{Introduction}

Reading was the ability to understand the material being read. In the area where English was considered as a foreign language, teaching reading skill became a vital point for the English teachers. Many experts asserted that reading was viewed as an active skill rather than a passive skill, which involves constant brain raking activity (Iwai, 2010; Oakhill and Beard, 1999; Carellet al, 1995; Hennings, 1994; Wood, 1991).

Reading comprehension was an essential language skill which supports the development of other language skills. Reading comprehension was the most important skill not only in the first native language learners but also in the second or foreign language learning because it demanded readers to be actively mark on the paper, working at constructing meaning by using their prior knowledge that already exist in their brain (Spears, 2000:5). Reading comprehension meant readers were required to comprehend word meaning, sentence meaning, paragraph meaning and text meaning (McWorther, 1986:90). Additionally, Wood (1991:57) confirms that reading improved vocabulary, and a larger vocabulary improved reading skill. Furthermore, reading could also improve grammar mastery which in result readers to read sensibly.

The students of the First Semester class of English Education Department of Islamic Institute of Darussalam Blokagung Banyuwangi in Academic Year 2018/2019 had some difficulties in understanding text, those were: 1) the students having low motivation in learning English, 2) student had different capability in understanding the material, and 3) they had no self-management.

Furthermore, the researcher conducted a preliminary study. This aimed to identify the student's problem in reading comprehension. The preliminary study was conducted on Thursday, November $1^{\text {st }}, 2018$. The 
students were given 70 minutes to read the text and to answer the questions based on the text given. The result of the preliminary study shown that their mean score of reading comprehension skill was poor. They took a long time for comprehend the text and they tent to read word by word and stumble on some difficult words they did not know. In this way, the students often lost a lot of their time so that they could not fulfill the task very well.

This study aimed to improve the students' reading skill through group work strategy. To measure their improvement in reading comprehension, the researcher had determined the criteria of success. The criteria of success was if more than $90 \%$ of the students reached the score above 70 .

Brown (2007:224) gave the definition of Group work, which generic term was covering a multiplicity of techniques in which two or more students were assigned a task that involves collaboration and self-initiated language. Gibson (2010:3) in his report also stated that "group teaching is the dominant pedagogic genre in English studies, on most modules in most departments taking up the lion's share of face-to-face interaction between lecturers and students".

Some studies was conducted in applying Group work strategy to improve the students' reading comprehension skill such as be done by Irawan (2016) at the Eleventh Year Students of SMK Pradana Giri Banyuwangi. He found that there were $91 \%$ of all students passed the test while the other 9\% students were failed the test. The criteria of success was if more than $90 \%$ of the students reached the score above 70 . It means that this strategy improved students' reading comprehension skill. Besides, $\mathrm{He}$ also found that this strategy could help to increase students' motivation, vocabularies, and self confident in doing the English reading text.

The Second study was conducted by umam, 2015. He applied the group work strategy in seven ${ }^{\text {th }}$ grade students of SMA Darussalam. It also could improve the student's reading comprehension skill.

\section{Research Method}

The design applied in this research was a CAR (Classroom Action Research). This was based on the reason that the writer aimed to solve the students' problem in reading comprehension and to improve their reading comprehension skill. In this research, the researcher did the activity at the First Semester class of English Education Department of Islamic Institute of Darussalam In Academic Year 2018/2019. Here, the researcher acted as the lecturer who conducted the process of teaching and learning in the classroom.

In this research, the researcher gathered the data by a test, to know "how well did the strategy solve the problems?". The focus of the observation was on the data related to the criteria of success that had been decided. In this stage, the researcher observed the class during and after the strategy had done in the class.

This study was done by two cycles. In the first cycle, the reseacher let them free to choose the members of their group and for the second cycle, the reseacher ditermined each group to be their member to minimize the domination of the higher achiever.

\section{Result and Discussion}

On the basis of the finding and the analysis of preliminary test, the researcher found that there were only 6 students or $24 \%$ passed the test and 19 students or $76 \%$ failed the test. 
After implementing the group work strategy in the first cycle, the researcher found that there were 16 students or $64 \%$ passed the test and 9 students or $36 \%$ failed the test. This was because they were not too interested in the text. Beside that There were the group consist of smart students only, and the group that consist of weak student only, So that the smart students could not taught the weak students in doing the task.

In the second cycle, the researcher choosen more interesting text than the first cycle; and make a heterogeneous language proficiency group, in which the weak and the strong reading students joined in a group collaborate to do the task. So as a result the students score increased. It could be seen that the 23 students or $92 \%$ passed the test and 2 students or $8 \%$ failed the test.

While, the previous study found that the implementation of group work strategy in the the first cycle was not applied optimally. Then, the action cycle was continued to the second cycle by revising the steps of applying group works strategy that were more applicable and effective to improve the students' reading comprehension achievement.

Since the previous study only revised the steps of applying group works strategy, the researcher not only revised the steps of applying group works strategy in this study, but also choosen more interesting text, and make a heterogeneous language proficiency group.

The improvement of students' learning result could be seen in table 1 below.

\begin{tabular}{|c|c|c|c|}
\hline No & Assessment & Percentage & Note \\
\hline 1. & Preliminary Study & $24 \%$ & The criteria of the success was if \\
2. & Cycle 1 & $64 \%$ & more than $90 \%$ of the students \\
3. & Cycle 2 & $92 \%$ & reached the score above 70 \\
\hline
\end{tabular}

Table 1. Student Improvement Result

From this data, the researcher found that any factors could improve reading comprehension, those were (1) the use of group work strategy and (2) textual factor.

Firstly, because students work in group, they were able to be managed and they could study effectively and efficiently. They were working together in a group so that they could participate on a task that has been clearly assigned. Moreover, they were able to carry out their task without direct and immediate supervision of teacher. Because the students who work in a team and they had a turn in each role. Furthermore, by taking the strong- and low-reading comprehension students in heterogeneous language proficiency group, in which the weak and the strong reading students joined in a group collaborate to do the task. The smart students taught the weak students in doing the task. As a result, there was no a class domination. That made the lesson more effective and efficient.

Secondly, the text that was not interesting effect on the student's mood and motivation. Text was also the factor that made the reader more engaging to read. So that selecting an interesting text was able to make students more enthusiastic. In the second cycle, the researcher choosen more interesting text than the first cycle; as a result the students score increased. Readability of 
the text (text difficulty) was not suitable for the students. it means that the students feel that the text too hard, so that the teacher selected the easier text for the second cycle. Content of the text did not attract student's attention. If more student interest to the text more student would engage their reading. For selecting reading material many criteria apply but for this purpose teacher should choose material that was not only interesting but worth spending time on So the lecturer selected more interesting topic on the second cycle.

\section{Conclusion}

In this research, the researcher concluded that group work strategy could improve students' reading skill. The students reading skill increased from $24 \%$, 64\%, to $92 \%$ (preliminary study, the first cycle and the second cycle). From this data, the researcher found that any factors could improve reading comprehension in class, those were (1) the use of group work strategy and (2) textual factor.

In grouping, the researcher put the students into mixed-proficiency group of five. That means put the strong student's reading ability with the low student's reading ability in a group. Besides, the researcher selected text that interest to them and also played video prologue to attract students' attention.

The result of the classroom action research (CAR) was hopefully expected to give more effective technique to the teacher mainly in the teaching process and give information dealing with strategies of reading comprehension trough group work strategy.

For the students, it could help to increase their motivation, vocabularies, and self-confident in doing the English reading text in order their score also increase.
For other researchers, the researcher also did hope that this research would give much useful knowledge about teaching and learning and it could be developed for further research in teaching and learning process.

\section{Acknowledgment}

This research was conducted under the Islamic Institute of Darussalam Blokagung Banyuwangi. The researcher would like to express his gratitude to the institution. Furthermore, the researcher as the Head of Undergraduate Program in English Education Department also want to motivate and engage the other lectures to conduct the research under the Islamic Institute of Darussalam Blokagung Banyuwangi, especially in English Education Department to express their gratitude to the institution.

\section{References}

Arikunto, S., Suhardjono, \& Supardi. (2010). Penelitian Tindakan Kelas $\left(10^{\text {th }} E d.\right)$. Jakarta: PT. Bumi Aksara.

Ary, D,. at. al. (1976) Introduction to Research in Education. New York : Holt, Rinehart and Winston.

Block, C.C., et al. (2001). Improving Comprehension Instruction. New York: Jossey Bass.

Brown, D. H. (2004). Language Assessment Principles and Calssroom Practices. New York: Pearson education. Inc.

Brown, H. (2007). Teaching by Principles: An Interactive Approach to Language Pedagogy. New York: Pearson Education, Inc.

Irawan, D.H. (2017) Using Small-Group Work to Improve Reading Comprehension of Eleventh Year Students of SMK Pradana Giri Banyuwangi. Thesis, tidak 
dipublikasikan. Universitas Islam Malang.

Latief, M.A. (2011). Research Methods on Language Learning. Malang. UM Press

Latief, M.A. (2012). Tanya Jawab Metode Penelitian Pembelajaran Bahasa. Malang. UM Press

McMillan, J.H. 1992. Education Research: Fundamental for Consumers. New York: Harper Collins Publisher

Nuttal, C. (1989). Teaching reading skills in a foreign language. Oxford: Richard Clay Ltd. Bungay, Sufflok.

Sulistyo, G.H. (2011). Reading for Meaning. Theories, Teaching Strategies and Assessment. Malang. UM Press

Tim Pengembangan Profesionalitas Guru. (2012). Pendidikan dan Pelatihan Profesi Guru Bidang Studi Bahasa Inggris. Jember : Kementrian Pendidikan Dan Kebudayaan 